\title{
Influence of Soil Fertilization Systems and Crop Rotation on Soil Chemical Properties
}

\author{
OANA MARIA MUSCALU (PLESCAN) 1, 2, VALENTIN NEDEFF1,3, IOAN GABRIEL SANDU4,5, ALEXANDRA DANA CHITIMUS ${ }^{1 *}$, \\ ELENA PARTAL ${ }^{6}$, NARCIS BARSAN ${ }^{1}$, DRAGOS IOAN RUSU ${ }^{1}$ \\ ${ }^{1}$ Vasile Alecsandri University of Bacau, Department of Environmental Engineering and Mechanical Engineering, 157 Marasesti \\ Str., 600115, Bacau, Romania \\ ${ }^{2}$ Romanian Waters National Administration of Siret Basin, 1 Cuza Voda Str., 600274, Bacau, Romania \\ ${ }^{3}$ Gheorghe Ionescu Sisesti Academy of Agricultural and Forestry Sciences, 61 Marasti Str., 011464, Bucharest, Romania \\ ${ }^{4}$ Gheorghe Asachi Technical University of lasi, Faculty of Materials Science \& Engineering 61A D. Mangeron Blvd, 700050, \\ lasi, Romania \\ ${ }^{5}$ Romanian Inventors Forum, 3 Sf Petru Movila, St. BI L11, Sc A, Et III, Ap 3, 700089, lasi, Romania \\ ${ }^{6}$ National Agricultural Research and Development Institute, 1 Nicolae Titulescu Str., 915200, Fundulea, Romania
}

\begin{abstract}
The purpose of this research has been to determine the influence of soil fertilizations systems (fertilization with: nitrogen, phosphorous, nitrogen and phosphorous, farmyard manure) on the chemical properties ( $\mathrm{pH}$, humus, aluminium and phosphorous content) of the soil. The experiments have been carried out in the experimental field of National Agricultural Research and Development Institute - Fundulea, Romania, for: wheat monoculture, 2-year crop rotation (wheat-corn), 3-year crop rotation (wheat-pea-corn), and 4-year crop rotation wheat-sun-flower-pea-corn. The lowest values of the phosphorous content in soil have been recorded for 3-year experimental variant (wheat-pea-corn), unfertilized ( $\left.a_{3} b_{1}\right)$, and the lowest aluminium content in soil $596 \mathrm{mg} / \mathrm{kg} \mathrm{d} . \mathrm{m}$.) has been recorded for the $a_{4} b_{5}$ experimental variant (4-year crop rotation wheat-sunflower-pea-corn) - fertilized with N90P75 kg/ha a.m., working depth: $15-30 \mathrm{~cm}$.
\end{abstract}

Keywords: pH, humus, aluminium, phosphorous, monoculture, crop rotation, fertilizers

Crop rotation should be applied so as to avoid the depletion of soil reserve of certain nutritional elements (nitrogen, phosphorous, potassium). A rational rotation has a positive influence on soil fertility and eventually on crops. With the rotation of the crops, there is also an adequate rotation of the systems of soil cultivation and fertilization [1-12].

Rotation of crops can have direct effects on the physical, chemical and biological properties of the soil. Rotation of crops has a major impact on crop health, soil degradation, soil water economy and, in general, rational crop management $[7,8]$.

Crop rotation is a strategy to prevent heavy losses of nutritional elements and it is also a powerful instrument when it comes to the concept of sustainable or organic agriculture [8, 13-21].

The importance of crop rotation is much higher in the case of modern agriculture, which implies intensive soil exploitation, by using fertilizers and an emphasis of humus mineralization $[3,8]$.

The research has the purpose of determining the influence of soil fertilization systems on chemical properties of the soil ( $\mathrm{pH}$, humus, aluminium and phosphorous content).

\section{Experimental part}

When choosing the sampling points, the research team took into account the topo-pedological base of the agrochemical cropping plots to determine the $\mathrm{pH}$, humus, aluminium and phosphorous content.

The study has been carried out at the National Agricultural Research and Development Institute-Fundulea, Romania (NARDI), a two-factor experience, stationary and multiannual, assembled in 1968 and up to date, referring to emphasizing the differentiation of soil features as an effect of soil crop rotation and fertilization with nitrogen (90kg N/ha a.m.), with phosphorous (75 kg P/ha a.m.), nitrogen and phosphorous (N90P75 kg/ha a.m. and farmyard manure for 48 years.

The experimental variants carried out at NARDI have been of the following type (fig. 1, table 1):

- crop rotation (Factor a)

-wheat monoculture: $a_{1}$;

-year rotation: wheat - corn: $a_{2}$ i

- 3-year rotation: wheat - peas - corn: $a_{3}$;

- 4-year rotation: wheat - sunflower - peas - corn: $a_{4}$.

- fertilization with (Factor b):

-unfertilized: $b_{\text {; }}$

-nitrogen - $90 \mathrm{~kg}$ N/ha a.m.: $b_{2}$;

-phosphorous - $75 \mathrm{~kg}$ P/ha a.m.: $b_{3}$;

-nitrogen and phosphorous - N90P'75 kg/ha a.m.: $\mathrm{b}_{4^{\prime}}$; -farmyard manure: $b_{5}$;

Table 1

SOIL CROP-ROTATION FOR THE PERIOD 2006-2016, I.E. FOR WHEAT, CORN, PEAS AND SUN-FLOWER CULTURE

\begin{tabular}{|c|c|c|c|c|}
\hline \multirow{2}{*}{ YEAR } & \multicolumn{4}{|c|}{ FACTOR } \\
\cline { 2 - 5 } & a1 & a2 & a3 & a4 \\
\hline 2016 & w & w & w & w \\
\hline 2015 & w & c & p & s \\
\hline 2014 & w & w & c & c \\
\hline 2013 & w & c & w & p \\
\hline 2012 & w & w & p & w \\
\hline 2011 & w & c & c & s \\
\hline 2010 & w & w & w & c \\
\hline 2009 & w & c & p & p \\
\hline 2008 & w & w & c & w \\
\hline 2007 & w & c & w & s \\
\hline 2006 & w & w & p & c \\
\hline
\end{tabular}

w - wheat (Triticum aestivum); $\mathrm{c}$ - com (Zea mays);

p - peas (Pisum sativum); s - sunflower (Helianthus anmuus). 
The soil samples have been taken on two depths:

- 0-15 cm;

- $15-30 \mathrm{~cm}$.

Fig. 1. Experimental variant by NARDI Fundulea, Romania

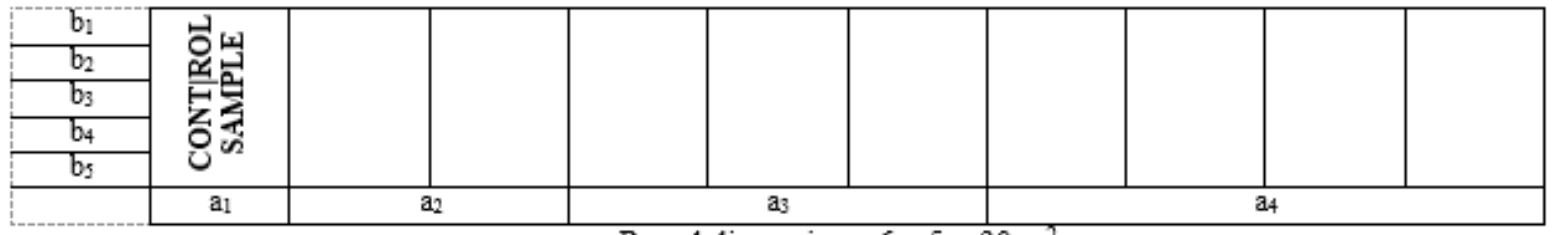

Parcel dimensions: $6 \times 5=30 \mathrm{~m}^{2}$

$\begin{array}{ll}\text { Soil samples } & \begin{array}{l}\text { 1. Drying at room temperature. } \\ 2 \text {. Screening the samples to obtain particles. The }\end{array}\end{array}$ soil is screened to a fraction smaller than $2 \mathrm{~mm}$.

3. Mineralization of soil samples in aqua regia.

Fig. 2. Soil samples preparation methods to determine aluminium content through atomic absorption spectrometry [22]

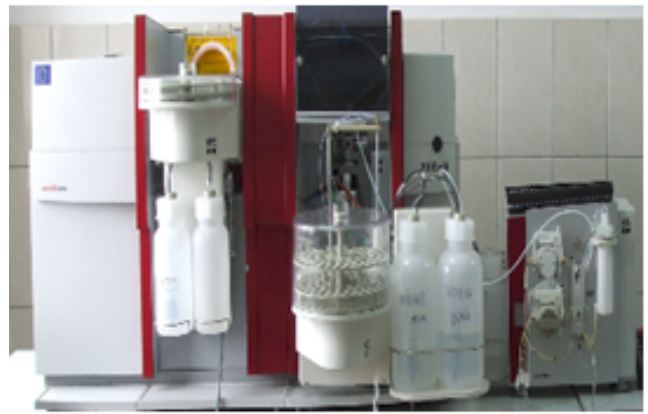

Fig. 3. Atomic absorption spectrometer (AAS), Zeenit 700 version [22]

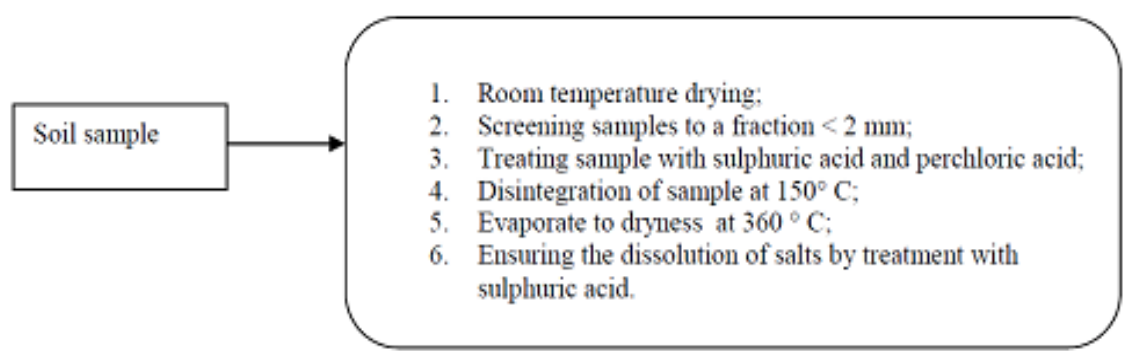

Fig. 4. Preparing methods of soil samples for determining the phosphorous by molecular spectrometry UV-Vis [23]
The soil samples have been taken in 2016. All soil samples have been collected as a composite form each parcel after wheat harvesting.

Figure 2 shows the processing method of the soil sample used to determine the soil's aluminum content.

The aluminium content in the soil samples has been determined by using the atomic absorption spectrometer (AAS), ZEENIT AAS version (Figure 3) [22].

Figure 4 shows the processing method of the soil sample used to determine the soil's phosphorous content. The phosphorous content in soil samples have been determined by using the UV/Vis spectrophotometer, SPECORD 200 version. [23, 24].

The humus content in soil has been determined according to STAS 7184/21-82 - Soils [25]. The chemical reaction of the soil ( $\mathrm{pH}$ ) has been determined according to SR 7184-13:2001 - Soils. Determining pH in water and saline slurries (mass/volume) and pulping to saturation [26].

\section{Results and discussions}

Table 2 shows the values experimentally determined for the four chemical properties of the soil, on the analysed parcels (control samples).

Table 3 shows the values experimentally determined for: $\mathrm{pH}$, humus, aluminium and phosphorous content, on parcels where fertilization and 2, 3 and 4-year crop rotations have been applied.

Chemical analysis of soil samples (experimental variants $-2,3$ and 4-year crop rotations) showed that the chemical reaction $(\mathrm{pH})$ of the soil significantly lowered compared to values registered in coil control samples - wheat monoculture (values between 5.1 for the wheat monoculture fertilized with nitrogen and phosphorous N90P75 kg/ha $-a_{1} b_{4^{\prime}}$ and 6.7 for the $a_{1} b_{1}$, unfertilized wheat monoculture variant).

We notice that the soil acidification increased for the $2 r$, 3 and 4-year crop rotations, following the application of fertilizers.

\begin{tabular}{|c|c|c|c|c|c|}
\hline $\begin{array}{c}\text { Experimental } \\
\text { variant }\end{array}$ & $\begin{array}{c}\text { Depth } \\
{[\mathbf{c m}]}\end{array}$ & $\begin{array}{c}\mathbf{p H} \\
{[\mathbf{p H} \text { units] }}\end{array}$ & Humus & $\begin{array}{c}\text { Al } \\
{[\mathbf{m g} / \mathbf{k g} \text { d.m.] }}\end{array}$ & $\begin{array}{c}\mathbf{P} \\
\text { [mg/kg d.m.] }\end{array}$ \\
\hline \multirow{2}{*}{$\mathbf{a}_{\mathbf{1}} \mathbf{b}_{\mathbf{1}}$} & $0-15$ & 6.7 & medium & 1264 & 134.52 \\
\cline { 2 - 6 } & $15-30$ & 6.6 & low & 2406 & 100.89 \\
\hline \multirow{2}{*}{$\mathbf{a}_{1} \mathbf{b}_{\mathbf{2}}$} & $0-15$ & 6.4 & low & 3058 & 128.9 \\
\cline { 2 - 6 } & $15-30$ & 6.5 & low & 3597 & 98.15 \\
\hline \multirow{2}{*}{$\mathbf{a}_{1} \mathbf{b}_{3}$} & $0-15$ & 5.5 & low & 2672,0 & 160.7 \\
\cline { 2 - 6 } & $15-30$ & 6.1 & low & 3275 & 145.4 \\
\hline \multirow{2}{*}{$\mathbf{a}_{1} \mathbf{b}_{\mathbf{4}}$} & $0-15$ & 5.3 & low & 1274 & 148.2 \\
\cline { 2 - 6 } & $15-30$ & 5.1 & low & 1548 & 139.9 \\
\hline \multirow{2}{*}{$\mathbf{a}_{1} \mathbf{b}_{5}$} & $0-15$ & 6.4 & low & 3306 & 154.2 \\
\cline { 2 - 6 } & $15-30$ & 6.3 & low -medium & 1224 & 99.6 \\
\hline
\end{tabular}

Table 2

VALUES EXPERIMENTALLY DETERMINED FOR THE FOUR CHEMICAL PROPERTIES OF THE SOIL, ON THE ANALYSED PARCELS (CONTROL SAMPLES) 
Table 3

VALUES EXPERIMENTALLY DETERMINED FOR THE FOUR CHEMICAL PROPERTIES OF THE SOIL, ON THE ANALYSED PARCELS

\begin{tabular}{|c|c|c|c|}
\hline $\begin{array}{c}\text { Experimental } \\
\text { variant }\end{array}$ & $\begin{array}{l}\text { Depth } \\
{[\mathrm{cm}]}\end{array}$ & $\begin{array}{c}\mathrm{pH} \\
{[\mathrm{pH} \text { units] }}\end{array}$ & Humus \\
\hline \multirow{2}{*}{$\mathbf{a}_{2} \mathbf{b}_{1}$} & $0-15$ & 6.5 & low \\
\hline & $15-30$ & 6.4 & low \\
\hline \multirow{2}{*}{$\mathbf{a}_{2} \mathbf{b}_{2}$} & $0-15$ & 6.2 & low \\
\hline & $15-30$ & 6.1 & low \\
\hline \multirow[b]{2}{*}{$\mathbf{a}_{2} \mathbf{b}_{3}$} & $0-15$ & 5.2 & low \\
\hline & $15-30$ & 5.1 & low \\
\hline \multirow{2}{*}{$\mathbf{a}_{2} \mathbf{b}_{4}$} & $0-15$ & 5.1 & low \\
\hline & $15-30$ & 5.1 & low \\
\hline \multirow{2}{*}{$\mathbf{a}_{2} \mathbf{b}_{5}$} & $0-15$ & 5.9 & low \\
\hline & $15-30$ & 5.8 & low \\
\hline \multirow{2}{*}{$\mathbf{a}_{3} \mathbf{b}_{1}$} & $0-15$ & 6.3 & low \\
\hline & $15-30$ & 6.2 & low \\
\hline \multirow[b]{2}{*}{$\mathbf{a}_{3} \mathbf{b}_{2}$} & $0-15$ & 6 & low \\
\hline & $15-30$ & 5.9 & low \\
\hline \multirow[b]{2}{*}{$\mathbf{a}_{3} \mathbf{b}_{3}$} & $0-15$ & 5.1 & low \\
\hline & $15-30$ & 5.0 & low \\
\hline \multirow{2}{*}{$\mathbf{a}_{3} \mathbf{b}_{4}$} & $0-15$ & 5.0 & low \\
\hline & $15-30$ & 5.0 & low \\
\hline \multirow{2}{*}{$\mathbf{a}_{3} \mathbf{b}_{5}$} & $0-15$ & 5.7 & low \\
\hline & $15-30$ & 5.8 & low \\
\hline \multirow{2}{*}{$\mathbf{a}_{4} \mathbf{b}_{1}$} & $0-15$ & 6.2 & low \\
\hline & $15-30$ & 6.2 & low \\
\hline \multirow{2}{*}{$\mathbf{a}_{4} \mathbf{b}_{2}$} & $0-15$ & 5.8 & low \\
\hline & $15-30$ & 5.8 & low \\
\hline \multirow{2}{*}{$\mathbf{a}_{4} \mathbf{b}_{3}$} & $0-15$ & 5.0 & low \\
\hline & $15-30$ & 5.0 & low \\
\hline \multirow{2}{*}{$\mathbf{a}_{4} \mathbf{b}_{4}$} & $0-15$ & 4.9 & low \\
\hline & $15-30$ & 5.0 & low \\
\hline \multirow{2}{*}{$\mathbf{a}_{4} \mathbf{b}_{5}$} & $0-15$ & 5.6 & low \\
\hline & $15-30$ & 5.5 & low \\
\hline
\end{tabular}

The lowest $p H$ value has been registered for the $a_{4} b_{4}$ experimental value - 4 year crop rotation - wheat -sunflower -corn - peas, fertilized with nitrogen and phosphorous - N90P75 kg/ha, the value being 4.9 .

The Al content value (fig. 5) for the experimental variants compared to the unfertilized wheat monoculture control sample $\left(a_{1} b_{1}\right)$ was:

- 0-15 cm: for the $a_{2} b_{1}$ experimental variant - 2- year rotation: wheat-corn, unfertilized, the aluminium content value was $53.24 \%$ lower than the values registered for the soil control sample;

- 15-30 cm: for the $a_{2} b_{1}$ experimental variant - 2-year rotation: wheat-corn, unfertilized, the aluminium content value was $30.9 \%$ lower than the values registered for the soil control sample;

- 0-15 cm: for the experimental variant -3 year rotation wheat - peas -corn $\left(a_{3} b_{1}\right)$, unfertilized, the aluminium content was $55.33 \%$ lower than the value registered in the soil control sample;

- 15-30 cm: for the experimental variant -3 year rotation - wheat -peas -corn, the aluminium content was $72.88 \%$ lower than the value registered in the soil control sample unfertilized wheat monoculture $\left(a_{1} b_{1}\right)$.

- 0-15 cm: for the $a_{4} b_{1}$ experimental variant -4 year rotation - wheat - sun-flower -corn -peas, unfertilized, the aluminium content was $57.12 \%$ lower than the value registered in the soil control sample;

- 15-30 cm: for the $a_{4} b_{1}$ experimental variant -4 year rotation - wheat - sun-flower - corn -peas, unfertilized, the aluminium content was $24.66 \%$ of the value registered in nitrogen ( $90 \mathrm{~kg} \mathrm{~N} / \mathrm{ha}$ ), the aluminium content was $84.23 \%$ lower than the value registered in the soil control sample;

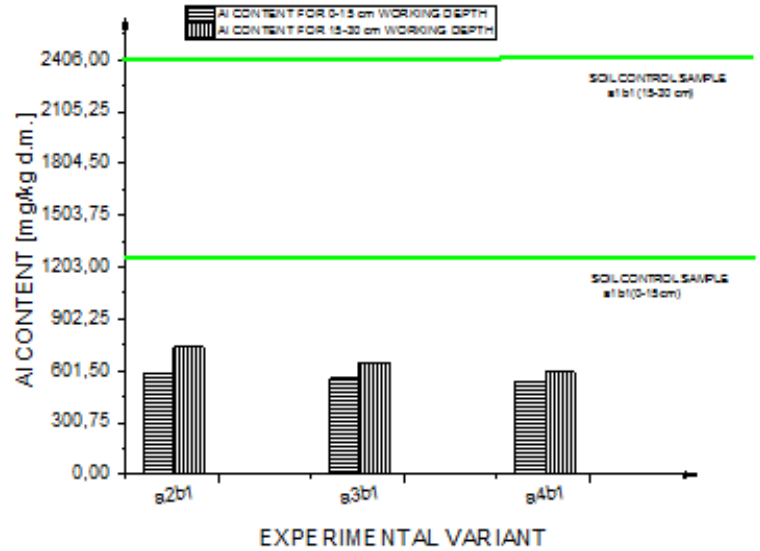

Fig. 5. Al content for the three analysed experimental variants, for the $0-15 \mathrm{~cm}$ and $15-30 \mathrm{~cm}$ working depths, compared to the soil control sample -the unfertilized wheat monoculture experimental variant $\left(a_{1} b_{1}\right)$

the soil control sample - unfertilized wheat monoculture $\left(a_{1} b_{1}\right)$.

The Al content value (fig. 6) registered in the case of the experimental variant-2 year rotation: wheat-corn, fertilized with nitrogen (90 kg N/ha) was $63.37 \%$ lower than the value registered in the soil parcel -wheat monoculture fertilized with nitrogen ( $90 \mathrm{~kg} \mathrm{~N} / \mathrm{ha}$ ), for the $0-15 \mathrm{~cm}$ working depth, and $83.69 \%$ lower than the coil control sample, for the $15-30 \mathrm{~cm}$ working depth, respectively.

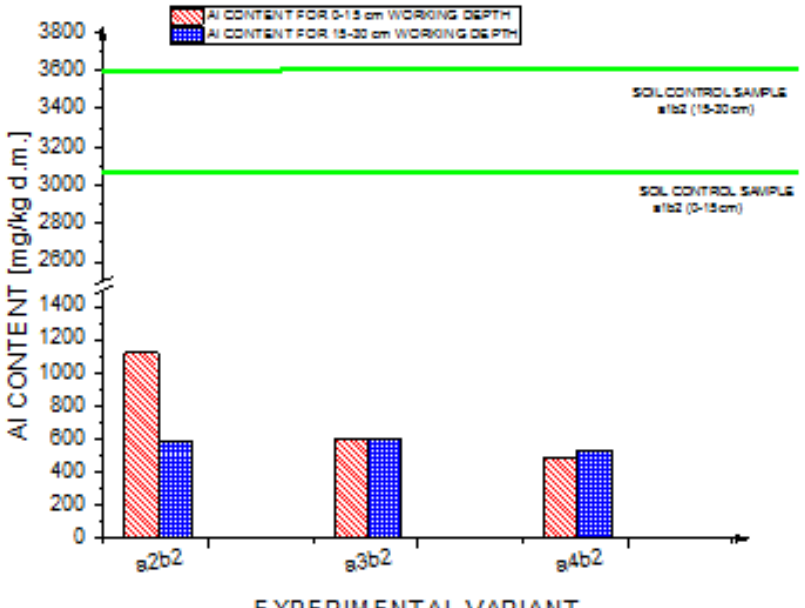

Fig. 6 . Al content for the three analysed experimental variants, for the $0-15 \mathrm{~cm}$ and $15-30 \mathrm{~cm}$ working depths, compared to the soil control sample - the wheat monoculture experimental variant fertilized with nitrogen - $90 \mathrm{~kg} \mathrm{~N} / \mathrm{ha}\left(\mathrm{a}_{1} \mathrm{~b}_{2}\right)$

In the case of the experimental Al content for the three analysed experimental variants, for the $0-15 \mathrm{~cm}$ and $15-30$ $\mathrm{cm}$ working depths, compared to the soil control sample the wheat monoculture experimental variantfertilized with nitrogen variant - 3 year rotation $\left(a_{3} b_{2}, 0-15 \mathrm{~cm}\right.$ working depth): wheat-peas-corn, fertilized with nitrogen (90 kg $\mathrm{N} / \mathrm{ha}$ ) the Al content in soil was $19.75 \%$ of the soil control sample (wheat monoculture, fertilized with nitrogen - 90 $\mathrm{kg} \mathrm{N} / \mathrm{ha}$ ), and $83.15 \%$ lower for the $15-30 \mathrm{~cm}$ working depth.

The Al content value (fig. 6) for the experimental variants compared to the wheat monoculture control sample fertilized with nitrogen $\left(a_{1} b_{2}\right)$ was:

- 0-15 cm: for the $a_{4} b_{2}$ experimental variant -4 year rotation - what - sunflower -corn -peas, fertilized with 
$-15-30 \mathrm{~cm}$ : for the $a_{4} b_{2}$ experimental variant -4 year rotation - what - sunflower -corn -peas, fertilized with nitrogen ( $90 \mathrm{~kg} \mathrm{~N} / \mathrm{ha}$ ), the aluminium content was $15.63 \%$ of the value registered in the soil control sample - wheat monoculture fertilized with nitrogen $\left(a_{1} b_{2}\right)$.

In the case of the experimental variant -2 year rotation $\left(a_{2} b_{3}, 0-15 \mathrm{~cm}\right.$ working depth): wheat-corn, fertilized with phosphorous ( $75 \mathrm{~kg} \mathrm{~N} / \mathrm{ha}$ ) the Al content in soil was $86.97 \%$ of the soil control sample (wheat monoculture, fertilized with phosphorous - $75 \mathrm{~kg} \mathrm{~N} / \mathrm{ha}$ ), and $56.06 \%$ lower for the 15-30 cm working depth (fig. 7).

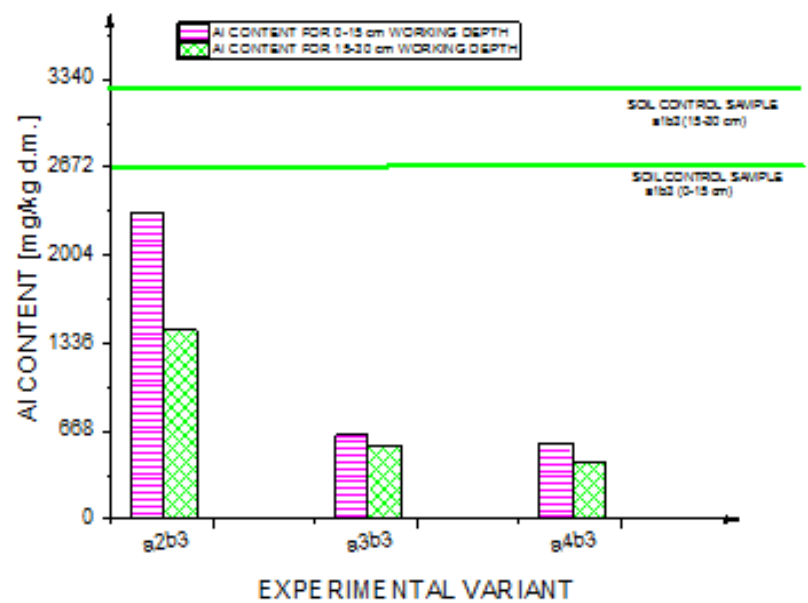

Fig. 7. Al content for the three analysed experimental variants, for the $0-15 \mathrm{~cm}$ and $15-30 \mathrm{~cm}$ working depths, compared to the soil control sample - the wheat monoculture experimental variant fertilized with phosphorous $-75 \mathrm{~kg} \mathrm{P} / \mathrm{ha}\left(\mathrm{a}_{1} \mathrm{~b}_{3}\right)$.

The Al content value (fig. 7) registered in the case of the experimental variant -3 year rotation: wheat - peas - corn, fertilized with phosphorous was $76.1 \%$ lower than the value registered in the soil parcel - wheat monoculture fertilized with phosphorous ( $75 \mathrm{~kg} \mathrm{~N} / \mathrm{ha}$ ), for the $0-15 \mathrm{~cm}$ working depth, and $83.03 \%$ low er than the soil control sample, for the $15-30 \mathrm{~cm}$ working depth, respectively.

For the $a_{4} b_{3}$ experimental variant (4 year rotation: wheatsunflower-corn-peas, fertilized with phosphorous - $75 \mathrm{~kg}$ $\mathrm{P} / \mathrm{ha}$ ), the registered Al content was $21.5 \%$ of the value registered in the soil control sample for the $0-15 \mathrm{~cm}$ working depth, and $13.33 \%$ of the soil control sample for the 15-30 $\mathrm{cm}$ working depth.

The Al content value (fig. 8) for the experimental variants compared to the unfertilized wheat monoculture control sample fertilized with nitrogen and phosphorous - N90P75 $\mathrm{kg} / \mathrm{ha}\left(\mathrm{a}_{1} \mathrm{~b}_{4}\right)$ was:

- 0-15 cm: for the $a_{2} b_{4}$ experimental variant -2 year rotation: wheat -corn, fertilized with nitrogen and phosphorous - N90P75 kg/ha, the aluminium content was $35 \%$ lower than the value registered in the soil control sample;

- 15-30 cm: for the $a_{2} b_{4}$ experimental variant -2 year rotation: wheat -corn, fertilized with nitrogen and phosphorous - N90P75 kg/ha, the aluminium content was $78.29 \%$ of the soil control sample;

- $0-15 \mathrm{~cm}$ : for the experimental variant -3 year rotation wheat -peas - corn $\left(a_{3} b_{4}\right)$, fertilized with nitrogen and phosphorous - N90P75 $\mathrm{kg} / \mathrm{ha}$, the aluminium content was $53.06 \%$ lower than the value registered in the soil control sample;

- 15-30 cm: for the $a_{3} b_{4}$ experimental variant - 3 year rotation wheat -peas - corn -, the aluminium content was $60.75 \%$ lower than the value registered in the soil control sample -wheat monoculture fertilized with nitrogen and phosphorous- N90P75 kg/ha $\left(a_{1} b_{4}\right)$.
- 0-15 cm: for the $a_{4} b_{4}$ experimental variant 4 year rotation - wheat - sunflower -corn -peas, fertilized with nitrogen and phosphorous - N90P75 kg/ha, the aluminium content was 54\% lower than the value registered in the soil control sample;

- 15-30 cm: for the $a_{4} b_{4}$ experimental variant 4 year rotation - wheat - sunflower -corn -peas, fertilized with nitrogen and phosphorous - N90P75 kg/ha, the aluminium content was $39.43 \%$ of the value registered in the soil control sample - wheatmonoculture fertilized with nitrogen and phosphorous - N90P75 kg/ha $\left(a_{1} b_{4}\right)$.

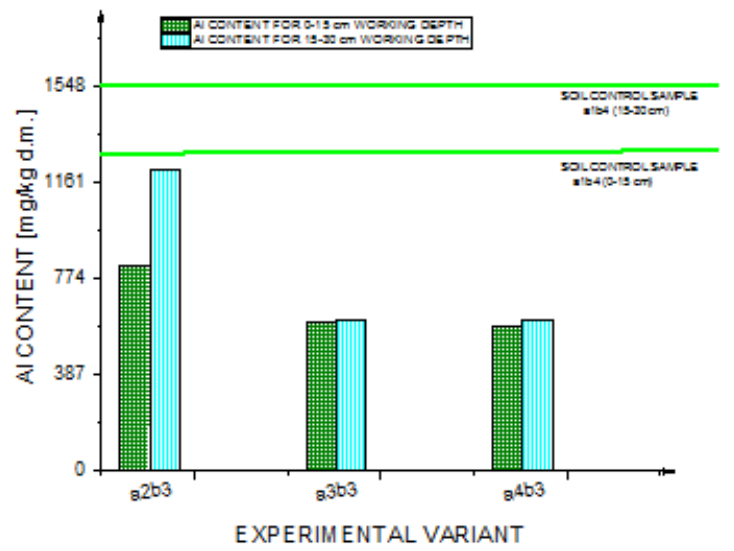

Fig. 8. Al content for the three analysed experimental variants, for the $0-15 \mathrm{~cm}$ and $15-30 \mathrm{~cm}$ working depths, compared to the soil control sample - the wheat monoculture experimental variant fertilized with nitrogen and phosphorous - N90P75 kg/ha $\left(a_{1} b_{4}\right)$

The aluminium content (fig. 9) registered in the case of experimental variant-2 year rotation: wheat-corn, fertilized with farmyard manure $\left(a_{2} b_{5}\right)$ was $10.16 \%$ lower than the value registered for the experimental variant -wheat monoculture fertilized with farmyard manure for the 0-15 $\mathrm{cm}$ working depth, and $55.22 \%$ lower than the soil control sample for the $15-30 \mathrm{~cm}$ working depth.

In the case of the experimental variant -3 year rotation $\left(a_{3} b_{5}, 0-15 \mathrm{~cm}\right.$ working depth): wheat-peas-corn, fertilized with farmyard manure, the aluminium content was $76.52 \%$ of the soil control sample (wheat monoculture, fertilized with farmyard manure), and 50.81\% lower for the15-30 $\mathrm{cm}$ working depth.

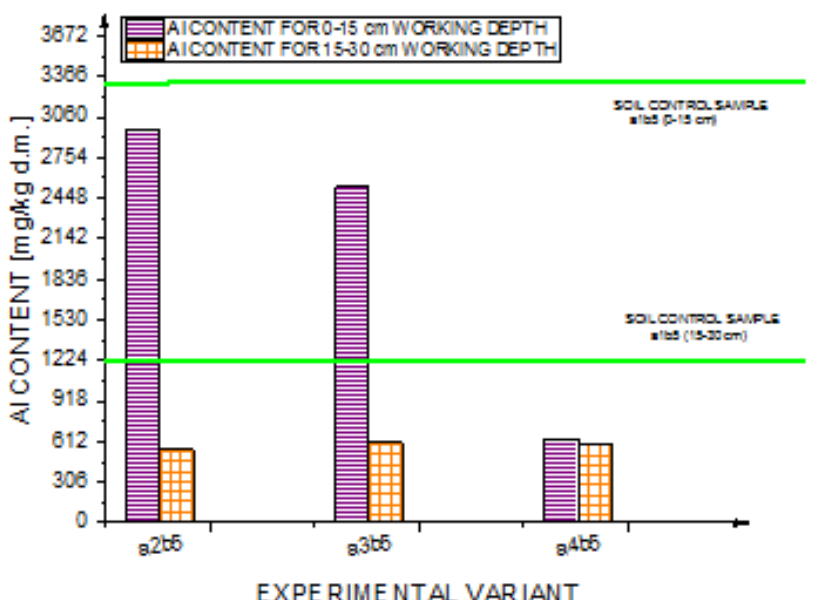

Fig. 9. Al content for the three analysed experimental variants, for the $0-15 \mathrm{~cm}$ and $15-30 \mathrm{~cm}$ working depths, compared to the soil control sample - the wheat monoculture experimental variant fertilized with farmyard manure $\left(a_{1} b_{5}\right)$

The aluminium content value (fig. 9) for the experimental variants compared to the control sample of wheat monoculture fertilized with farmyard manure $\left(a_{1} b_{5}\right)$ was: 
- 0-15 cm: for the experimental variant $a_{4} b_{5}-4$ year rotation - wheat - sunflower - corn - peas, fertlized with farmyard manure, the aluminium content was $80.83 \%$ lower than the value registered in the soil control sample;

- 15-30 cm: for the experimental variant $a_{4} b_{5}-4$ year rotation - wheat - sunflower -corn - peas, fertilizized with farmyard manure, the aluminium content was $48.69 \%$ of the value registered in the soil control sample - wheat monoculture fertilized with farmyard manure $\left(a_{1} b_{5}\right)$.

The soil humus content proved to be higher only in soil control samples, for the experimental variants:

- $a_{1} b_{1}$ - unfertilized wheatmonoculture, $0-15 \mathrm{~cm}$ working depth, the humus content was medium;

- $a_{1} b_{5}$ - wheat monoculture fertilized with farmyard manure, $0-15 \mathrm{~cm}$ working depth, the humus content was low to medium.

The humus content was low for 2, 3, and 4 year crop rotations, after applying the fertilizers.

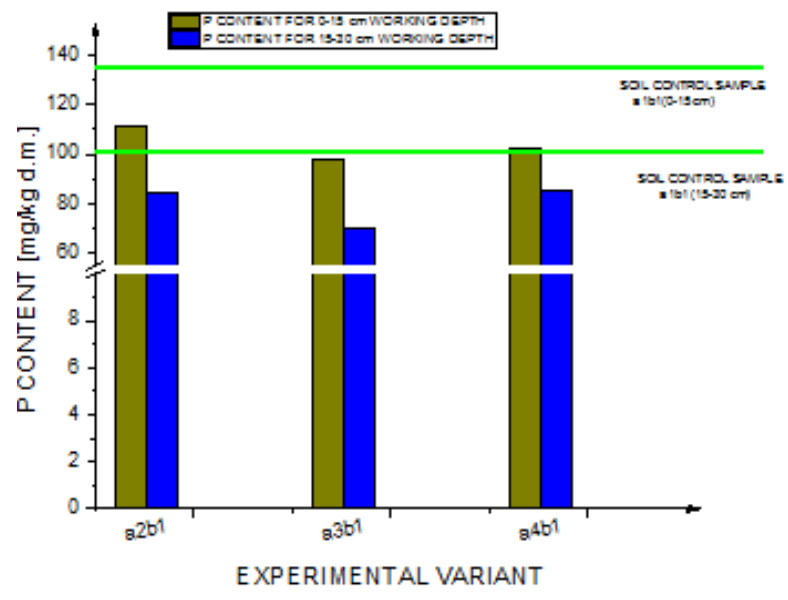

Fig. 10. The phosphorous content for the three analysed experimental variants, for the $0-15 \mathrm{~cm}$ and $15-30 \mathrm{~cm}$ working depths, compared to the soil control sample - the unfertilized wheat monoculture experimental variant $\left(a_{1} b_{1}\right)$

The phosphorous content value (fig. 10) for the experimental variants compared to the unfertilized wheat monoculture control sample $\left(a_{1} b_{1}\right)$ was:

$-0-15 \mathrm{~cm}$ : the $a_{2} b_{1}$ experimental variant -2 year rotation -wheat -corn, the phosphorous content value was $17.56 \%$ lower than the value registered in the soil control sample;

$-15-30 \mathrm{~cm}$ : the $a_{2} b$ experimental variant -2 year rotation - wheat-corn, unfertilized, the phosphorous content value was $83.32 \%$ of the value registered in the soil control sample;

- 0-15 cm: for the experimental variant -3 year rotation wheat -peas -corn $\left(a_{3} b_{1}\right)$, unfertilized, the phosphorous content value was $27.52 \%$ lower than the value registered in the soil control sample;

- 15-30 cm: for the $a_{3} b_{1}$ experimental variant -3 year wheat -peas -corn $\left(a_{3} b_{1}\right)$, the phosphorous content value was $30.22 \%$ lower than the value registered in the soil control sample -unfertilized wheat monoculture $\left(a_{1} b_{1}\right)$.

- 0-15 cm: for the $a_{4} b_{1}$ experimental variant -4 year rotation -wheat -sunflower - peas -corn, the phosphorous content value was $23.72 \%$ lower than the value registered in the soil control sample;

- 15-30 cm: for the $a b$ experimental variant -4 year rotation -wheat -peas -sunflower -corn, the phosphorous content value was $84.64 \%$ of the value registered in the soil control sample -unfertilized wheat monoculture $\left(a_{1} b_{1}\right)$.

The phosphorous content value (fig. 11) registered in the case of the experimental variant -2 year crop rotation: wheat-corn, fertilized with nitrogen ( $90 \mathrm{~kg} \mathrm{~N} / \mathrm{ha}$ ) was
40.06\% lower than the value registered for the experimental variant -wheat monoculture fertilized with nitrogen $190 \mathrm{~kg}$ $\mathrm{N} / \mathrm{ha}$ ), for the $0-15 \mathrm{~cm}$ working depth, and $10.34 \%$ lower than the soil control sample for the $15-30 \mathrm{~cm}$ working depth.

In the case of the experimental variant -3 year rotation $\left(a_{3} b_{2}, 0-15 \mathrm{~cm}\right.$ working depth): wheat-peas-corn, fertilized with nitrogen ( $90 \mathrm{~kg} \mathrm{~N} / \mathrm{ha}$ ), the phosphorous content was $82.23 \%$ of the soil control sample (wheat monoculture, fertilized with nitrogen ( $90 \mathrm{~kg} \mathrm{~N} / \mathrm{ha}$ ), and $20.21 \%$ lower for the $15-30 \mathrm{~cm}$ working depth.

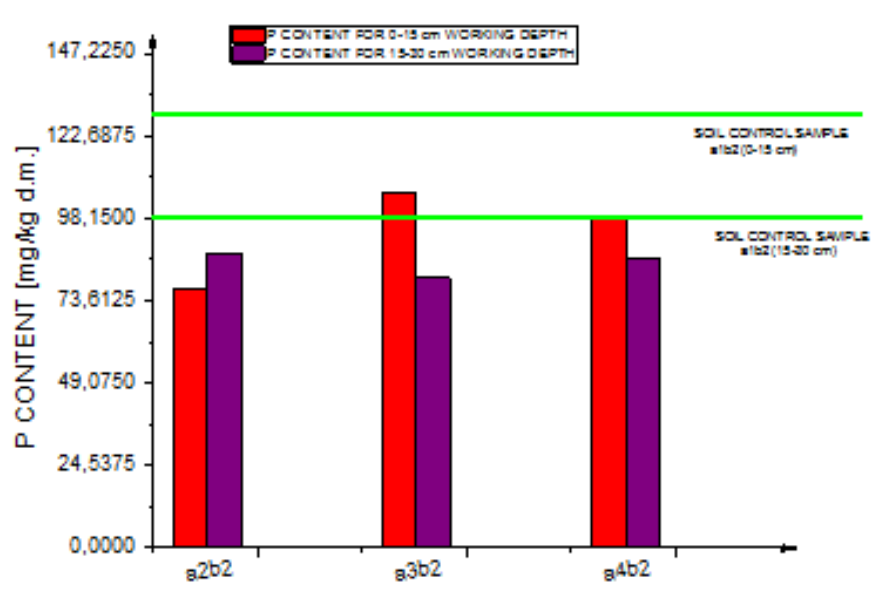

EXPE RIME NTAL VAR IANT

Fig. 11. The phosphorous content for the three analysed experimental variants, for the $0-15 \mathrm{~cm}$ and $15-30 \mathrm{~cm}$ working depths, compared to the soil control sample - the wheat monoculture experimental variant with nitrogen - $90 \mathrm{~kg} \mathrm{~N} / \mathrm{ha}\left(a_{1} b_{2}\right)$

The phosphorous content value (fig. 11) for the experimental variants compared to the control sample of the wheat monoculture fertilized with nitrogen $\left(a_{1}, b_{2}\right.$ was:

- 0-15 cm: for the $a_{4} b_{2}$ experimental variant -4 year rotation -wheat-sunflower peas -corn $\left(a_{3} b_{1}\right)$, fertilized with phosphorous ( $90 \mathrm{~kg} \mathrm{~N} / \mathrm{ha}$ ), the phosphorous content was $24.04 \%$ lower than the value registered in the soil control sample;

- 15-30 cm: for the $a_{4} b_{2}$ experimental variant -4 year rotation -wheat-sunflower peas -corn $\left(a_{3} b_{1}\right)$, fertilized with phosphorous ( $90 \mathrm{~kg} \mathrm{~N} / \mathrm{ha}$ ), the phosphorous content was $85.34 \%$ of the value registered in the soil control sample wheat monoculture fertilized with nitrogen $\left(a_{1} b_{2}\right)$.

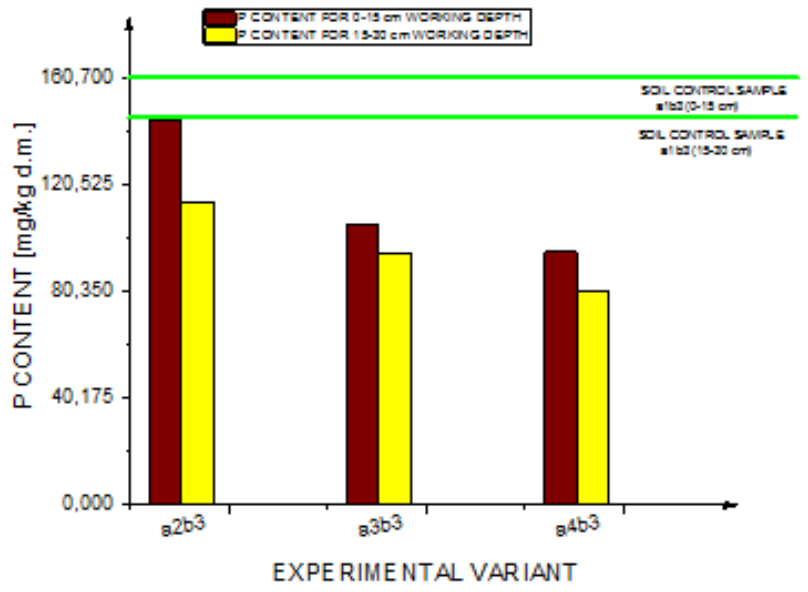

Fig. 12. The phosphorous content for the three analysed experimental variants, for the $0-15 \mathrm{~cm}$ and $15-30 \mathrm{~cm}$ working depths, compared to the soil control sample - the wheat monoculture experimental variant fertilized with phosphorous -75 $\mathrm{kg} P /$ ha $\left(a_{1} b_{3}\right)$ 
In the case of the experimental variant - 2 year rotation $\left(a_{2} b_{3}, 0-15 \mathrm{~cm}\right.$ working depth): wheat-corn, fertilized with phosphorous ( $75 \mathrm{~kg} \mathrm{~N} / \mathrm{ha}$ ), the phosphorous content in soil (fig. 12) was $89.93 \%$ of the soil control sample (wheat monoculture, fertilized with phosphorous ( $75 \mathrm{~kg} \mathrm{~N} / \mathrm{ha}$ ), and $21.54 \%$ lower for the15-30 cm working depth.

The phosphorous content value (fig. 12) registered in the case of the experimental variant - 3 year crop rotation: wheat-peas-corn, fertilized with phosphorous was $34.23 \%$ lower than the value registered for the experimental variant - wheat monoculture fertilized with phosphorous $(75 \mathrm{~kg}$ $\mathrm{N} / \mathrm{ha}$ ), for the $0-15 \mathrm{~cm}$ working depth, and $34.86 \%$ lower than the soil control sample for the $15-30 \mathrm{~cm}$ working depth.

In the case of the $a_{4} b_{3}$ experimental variant - 4 year rotation: wheat-sunflow er-peas-corn, fertilized with phosphorous ( $75 \mathrm{~kg} \mathrm{~N} / \mathrm{ha}$ ), the phosphorous content was $59.36 \%$ of the soil control sample (for the $0-15 \mathrm{~cm}$ working depth), and $55.5 \%$ of the soil control sample for the15-30 $\mathrm{cm}$ working depth.

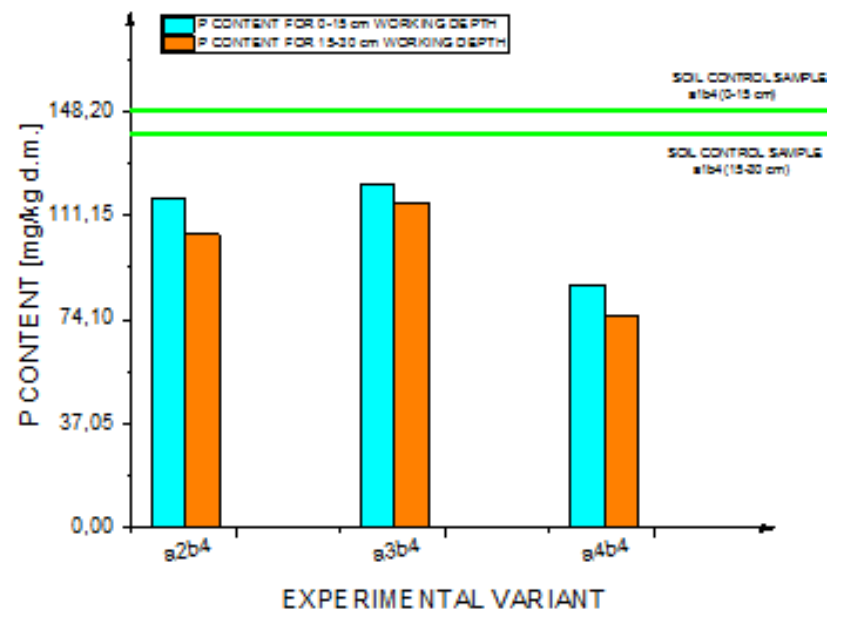

Fig. 13. The phosphorous content for the three analysed experimental variants, for the $0-15 \mathrm{~cm}$ and $15-30 \mathrm{~cm}$ working depths, compared to the soil control sample - the wheat monoculture experimental variant fertilized with nitrogen and phosphorous - N90P75 kg/ha $\left(a_{1} b_{4}\right)$

The phosphorous content value (fig. 13) for the experimental variants compared to the control sample of the wheat monoculture fertilized with nitrogen and phosphorous N90P75 kg/ha $\left(a_{1} b_{4}\right.$ was:

- 0-15 cm: for the $a_{2} b_{4}$ experimental variant -2 year rotation wheat -corn fertilized with nitrogen and phosphorous (N90P75kg N/ha), the phosphorous content was $20.91 \%$ lower than the value registered in the soil control sample.

- 15-30 cm: for the $a_{4} b_{2}$ experimental variant - 2-year rotation wheat -corn fertilized with nitrogen and phosphorous (N90P75kg N/ha), the phosphorous content was $74.71 \%$ of the value registered in the soil control sample.

- 0-15 cm: for the experimental variant -3 year rotation wheat -peas-corn $\left(a_{3} b_{4}\right)$, fertilized with nitrogen and phosphorous (N90P75kg N/ha), the phosphorous content was $17.40 \%$ lower than the value registered in the soil control sample

- 15-30 cm: for the $a_{3} b_{4}$ experimental variant -3 year rotation wheat -peas-corn the phosphorous content was $17.36 \%$ lower than the value registered in the soil control sample - wheat monoculture fertilized with nitrogen and phosphorous (N90P75kg N/ha $\left(a_{4} b_{4}\right)$ :

- 0-15 cm: for the $a_{4} b_{4}$ experimental variant -4 year rotation wheat-sunflow er -peas-corn, fertilized with nitrogen and phosphorous (N90P75kg N/ha), the phosphorous content was $41.76 \%$ lower than the value registered in the soil control sample.

$-15-30 \mathrm{~cm}$ : for the $a_{4} b_{4}$ experimental variant -4 year rotation wheat-sunflower -peas-corn, fertilized with nitrogen and phosphorous (N90P75kg N/ha), the phosphorous content was $53.75 \%$ of the value registered in the soil control sample - wheat monoculture fertilized with nitrogen and phosphorous (N90P75kg N/ha $\left(a_{1} b_{4}\right)$.

The phosphorous content value (fig. 14) registered in the case of the experimental variant -2 year crop rotation: wheat-corn, fertilized with farmyard manure $\left(a_{2} b_{5}\right)$ was $38.99 \%$ lower than the value registered for the experimental variant - wheat monoculture fertilized with farmyard manure for the $0-15 \mathrm{~cm}$ working depth, and $21.53 \%$ lower than the soil control sample for the $15-30 \mathrm{~cm}$ working depth

In the case of the $a_{1} b_{3}$ experimental variant - 3-year rotation ( $a_{3} b_{5}, 0-15 \mathrm{~cm}$ working depth): wheat-peas-corn, fertilized with farmyard manure, the soil phosphorous content was $78.08 \%$ of the soil control sample (wheat monoculture, fertilized with farmyard manure), and $34.03 \%$ lower for the 15-30 cm working depth.

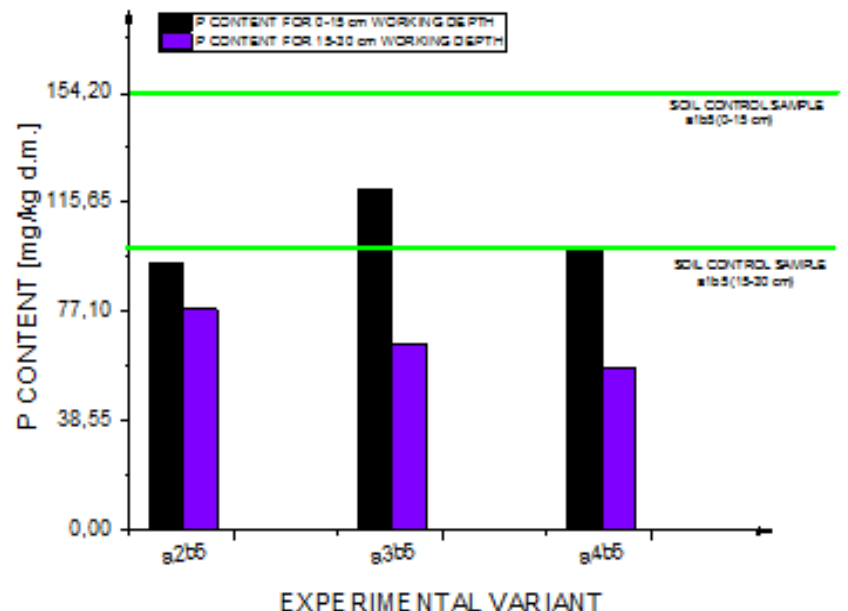

Fig. 14. The phosphorous content for the three analysed experimental variants, for the $0-15 \mathrm{~cm}$ and $15-30 \mathrm{~cm}$ working depths, compared to the soil control sample - the wheat monoculture experimental variant fertilized with farmyard manure $\left(a_{1} b_{5}\right)$

The phosphorous content value (fig. 14) for the experimental variants compared to the control sample of the wheat monoculture fertilized with farmyard manure $\left(a_{1} b_{5}\right.$ was:

- $0-15 \mathrm{~cm}$ : for the $a_{4} b_{5}$ experimental variant -4 year crop rotation - wheat - sunflower -corn - peas, fertilized with farmyard manure, the phosphorous content was $34.88 \%$ lower than the value registered in the soil control sample;

- 15-30 cm: for the $a_{4} b_{5}$ experimental variant -4 year crop rotation - wheat - sunflower -corn -peas, fertilized with farmyard manure, the phosphorous content was 57.83 $\%$ of the value registered in the soil control sample wheat monoculture fertilized with farmyard manure $\left(a_{1} b_{5}\right)$.

The variation of aluminium content in soil is the result of:

- high stabilization capacity of metals in soil of the plant species Triticum aestivum (wheat) through the phytostabilization process.

- absorption capacity of plant species Zea mays and Helianthus annuus through the continual phytoextraction process.

The variation of phosphorous content is soil is due to the absorption capacity of the plant species Pisum sativum, through the continual phytoextraction process. 


\section{Conclusions}

The research carried out in 2016 with regard to the influence of the soil fertilizations systems and crop rotation on chemical properties of the soil emphasized the following aspects:

- the soil reaction significantly modified, in the control samples of wheat monoculture, but mainly in the case of 3-year and 4-year rotation, as a result of the application of fertilizers;

- mineral fertilization (N90P75 kg/ha) lowered the most the soil's $\mathrm{pH}$ value, while the farmyard manure lead to an increment of the $\mathrm{pH}$;

- the humus content of the soil was higher in the control samples of wheatmonoculture (experimental variants $a_{1} b_{1}$ -unfertilized wheat monoculture, $0-15 \mathrm{~cm}$ working depth, the humus content was medium, $a_{1} b_{5}$ - wheatmonoculture fertilized with farmyard manure, $15-30 \mathrm{~cm}$ working depth, the humus content was low to medium), while for the 2,3 , and 4-year crop rotations the humus content was low;

- the lowering of aluminium content in soil for the2, 3, and 4-year crop rotations compared to wheatmonoculture control samples is due to the capacity of plant species Pisum sativum, Zea mays and Helianthus annuusto absorb the aluminium through the continual phytoextraction process;

- the lowest phosphorous content value in soil is registered for the 3-year crop rotations, for the $a_{3} b_{1}$ experimental value -3-year rotation: wheat-peas-corn, unfertilized, due to the capacity of the Pisum sativum species to absorb the phosphorous through continual phytoextraction.

\section{References}

1.SANGAR, K., RIFAT, H., MUHAMMAD, SHAKIR, F., QAISER, H., NOSHEN A.A., Advances in Crop Science and Technology, 6, no. 1, 2017, p. 328. 2.UZOMA, K.C., INOUE, M., ANDRY, H., FUJ IMAKI, H., ZAHOOR, A., NISHIHARA, E., Soil Use and Management, 27, 2011, p. 205.

3.YANG, R., SU, Y.,WANG, T., YANG, Q., Journal of Integrative Agriculture, 15, no. 3, 2017, p. 658.

4.IRIMIA, O., NEDEFF, V., PANAINTE LEHÃDUa , M., TOMOZEI, C., Journal of Engineering Studies and Research, 22, no. 1, 2016, p. 64. 5.DINU, C., UNGUREANU, E.M., VASILE, G.G., KIM, L., IONESCU, I., ENE, C., SIMION, M., Rev. Chim. (Bucharest), 69, no. 1, 2018, p.14. 6.MASU, S., COJ OCARIU, L., GRECU, E., MORARIU, F., BORDEAN, F.D., HORABLAGA, M., NITA, L., NITA, S., Lolium Perenne - A phytoremediation option in case of total petroleum hydrocarbons polluted soils, Rev. Chim. (Bucharest), 69, no. 5, 2018, p. 1110.

7.CHITIMUS, A.D., NEDEFF, V., MOSNEGUTU, E.F. PANAINTE M., Environmental Engineering and Management] ournal, 11, no. 12, 2012, p. 2161.
8.MUSCALU (PLE'CAN), O.M., NEDEFF, V., CHITIMUS, A.D., PARTAL, E., MOSNEGUTU, E., RUSU, I.D., Rev. Chim. (Bucharest), 69, no. 11, 2018, p. 3106.

9. BELCIU, M.C., MOSNEGUTU, E.F., NEDEFF, V., CHITIMUS, A.D., BARSAN, N., FIORE, S., Environmental Engineering and Management Journal, 15, no. 3, p. 2057.

10.CHITIMUS, A.D., Studies and researches on the influence of mechanical and physical properties of soil in self-cleaning and cleaning, PhD Thesis, Vasile Alecsandri University of Bacau, Romania, 2011.

11.CHITIMUS, A.D., NEDEFF, V., MOSNEGUTU, E., LAZÃR, G., Soil Cleaning Techniques (in Romanian), Editura Alma Mater Bacãu, 2012, p. 51.

12.BALEMI, T., NEGISHO, K., J ournal of Soil Science and Plant Nutrition, 12, no. 3, 2012, p. 547.

13. CHITIMUS, A.D., NEDEFF, V., LAZAR, G., Journal of Engineering Studies and Research, 17, no. 4, 2011, p. 24.

14.CHITIMUS, A.D., RADU, C., NEDEFF, V., MOSNEGUTU, E., BARSAN, N., Scientific Study \& Research Chemistry $\&$ Chemical Engineering, Biotechnology, Food Industry, 17, no. 4, 2016, p. 381.

15.CHITIMUS, A.D., BARSAN, N., NEDEFF, V., MOSNEGUTU, E., MUSCALU (PLESCAN), O., Studies and research concerning the influence of liquid pollutants' leaching speed in the soil on the process of cleaning and self-cleaning, 17th International Multidisciplinary Scientific GeoConference SGEM 2017, 17, no. 51, 2017, p. 859.

16.CLEMENS, S., PALMGREN, M.G., KRÄMER, U., Plant Science, 7, 2002, p. 309-315.

17.GREGER, M., Metal availability, uptake, transport and accumulation in plants, in Heavy Metal Stress in Plants - from biomolecules to ecosystems, Springer Heidelberg, 2004, pp. 1-27.

18.RADU, C., CHITIMUS, A.D., TURCU, M., ARDELEANU, G., BELCIU M., Environmental Engineering and Management Journal, 13, no. 7, 2014, p. 1687.

19.RADU, C., NEDEFF, V., CHITIMUS, A.D., Journal of Engineering Studies and Research, 19, no. 2, 2013, p. 89.

20.SENILA, M., LEVEI, E., MICLEAN, M., SENILA, L., STEFANESCU, L., MÃRGINEAN, S., OZUNU, A., ROMAN, C., Environmental Engineering and Management J ournal, 10, 2011, p. 59.

21. SAMREEN, S., INAM, A., KHAN, A.A., International J ournal of Conservation Science, 8, no. 4, 2017, p. 695.

22.*** Atomic absorption spectrometry (AAS) ZEEnit 700, Operating Manual, 2009.

23.*** Spectrophotometer SPECORD 200 UV-VIS, Operating Manual Analytik Jena, 2007.

24. *** SR EN ISO 6878/ 2005- Water quality- Determination of phosphorus - Ammonium molybdate spectrometric method 25. ***STAS 7184/21-82- Soils. Humus content determination 26. ***SR 7184-13:2001 - Soils. Determination of pH in water and saline suspensions (mass/volume) and in saturated paste

$\overline{\text { Manuscript received: } 5.09 .2018}$ 